\title{
COMFORT AND ENERGY PERFORMANCE ANALYSIS OF A HERITAGE RESIDENTIAL BUILDING IN SHANGHAI
}

\author{
${ }^{1}$ Chu XIAOHUI, ${ }^{2}$ Ganjali Bonjar Mohammad REZA \\ ${ }^{3}$ Gantumur TSOVOODAVAA, ${ }^{4}$ Rowell Ray Lim SHIH, ${ }^{5}$ Balint BARANYAI ${ }^{*}$ \\ 1,2,3,4 Marcel Breuer Doctoral School, Faculty of Engineering and Information Technology \\ University of Pécs, Boszorkány u. 2, H-7624 Pécs, Hungary, e-mail: ${ }^{1} 525407983 @$ qq.com \\ ${ }^{2}$ mohammadrezaa.ganjali@gmail.com, ${ }^{3}$ tsovoog@gmail.com, ${ }^{4}$ rowellshih@yahoo.com \\ ${ }^{3}$ Mongolian University of Science and Technology, School of Civil Engineering and \\ Architecture, Ulaanbaatar, Mongolia \\ ${ }^{4}$ University of San Carlos, School of Architecture, Fine Arts and Design, Cebu, Philippines \\ ${ }^{5}$ Department of Energy Design, Faculty of Engineering and Information Technology \\ Boszorkány u. 2 and János Szentágothai Research Center, Ifjúság u. 20 \\ University of Pécs, H-7624 Pécs, Hungary, e-mail: balint.baranyai@mik.pte.hu
}

Received 2 January 2018; accepted 4 October 2018

\begin{abstract}
Along with its rapid growth in economy, the protection of heritage buildings has recently gained importance and awareness in China. This paper investigates the energy performance of a heritage building (Wang's House) in Shanghai, as well as the thermal comfort of the users, using dynamic thermal simulations. The analysis showed that heating accounts as the highest energy demand, followed by cooling and lighting. The resulting study will help the authors to identify various sustainable strategies to improve users comfort as well as reduce the energy demand of heritage buildings in China.
\end{abstract}

Keywords: Heritage residual building, Dynamic energy and climate simulation, Thermal comfort performance

\section{Introduction}

Building energy accounts for approximately $40 \%$ of the total energy consumption in the United States, European Union and other developed countries [1]. In China, the number was $19.1 \%$ in 2012 and increased approximately $8.3 \%$ annually from 2001 to 2012 [2]. In the last decade, there has been an increased interest to the enhancement of energy performance and comfort conditions of historic buildings [3], [4]. Energy consumption analysis on heritage buildings have been done in previous studies, in order to identify the energy demand and ensure cost savings in the future [3]. In literature, there have been studies done on comfort analysis on Chinese heritage houses using

\footnotetext{
${ }^{*}$ Corresponding Author
} 
numerical simulation. Fei et al. initiated a quantitative analysis on a heritage building in Zhejiang province [5]. Liu et al. investigated the thermal and energy analysis of a vernacular house in Yinchuan province in order to analyze the effects of passive cooling [6]. Therefore, the integration of energy efficiency solutions has huge potential for improving the sustainability of historic buildings. This historic building is highly protected by Songjiang district. Furthermore, this building is a typical traditional of Shanghai, which motivated us to choose it as a research sample for further restoration. The significant of this research is the comprehensive energy analysis while taking into consideration the comfort parameters. Often misconception exists about heritage buildings, considering them to perform badly in terms of energy conservation. However, a study in literature shows this is not always the case [7]. In this study, a building energy and comfort performance assessment was carried out about a heritage residential building in Shanghai. Beside energy simulations in hourly resolution about the existing house, also investigation on energy saving potentials was analyzed.

The objective of this study is to perform thermal and energy assessment analysis of Wang's House, which is a historical architecture located in China. Wang's House is located at the junction of Zhongshan West Road and Yushu Road in Songjiang District of Shanghai and was built during the late Qing Dynasty (1840-1912). Wang's House is a good example of an early Chinese light industry family-style workshop and the government of Songjiang District of Shanghai has recently registered the house as a historical structure [8]. The house has three courtyard buildings: two located on the Southwest side (Courtyard A1 \& A2) and one on the North side (Courtyard B) (Fig. 1a). The southwest side courtyard is well preserved (Fig. 1b) while the north side courtyard building was used as a dyeing workshop. The entire building compound covers an area of 2,108 square meters. In this paper, the Southwest side was selected as the case study, which has a total area of 180 square meters. The resulting investigation will therefore be used as energy saving measures that would also contribute to the preservation of the original architectural expression of the house. In this analysis, the dynamic simulation software IDA ICE 4.8 was used (Fig. 2).

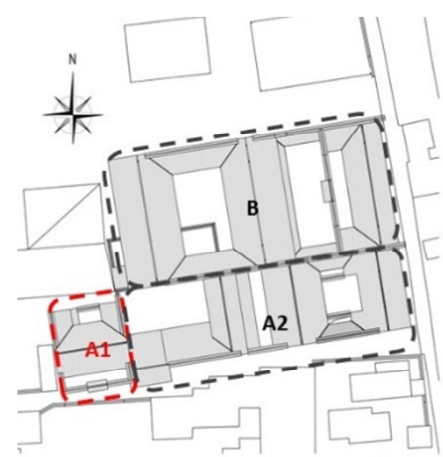

a)

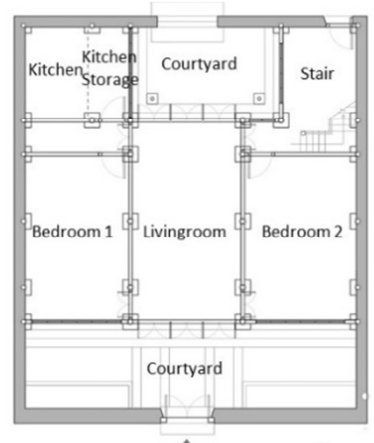

b)

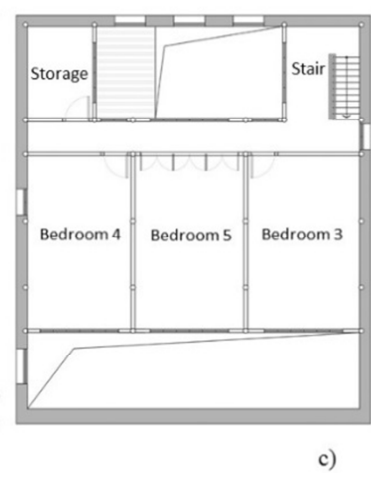

c)

Fig. 1. a) B: The North side courtyard, A1 and A2: Southwest side courtyard; b) First floor plan of A1; c) Second floor plan of A1 


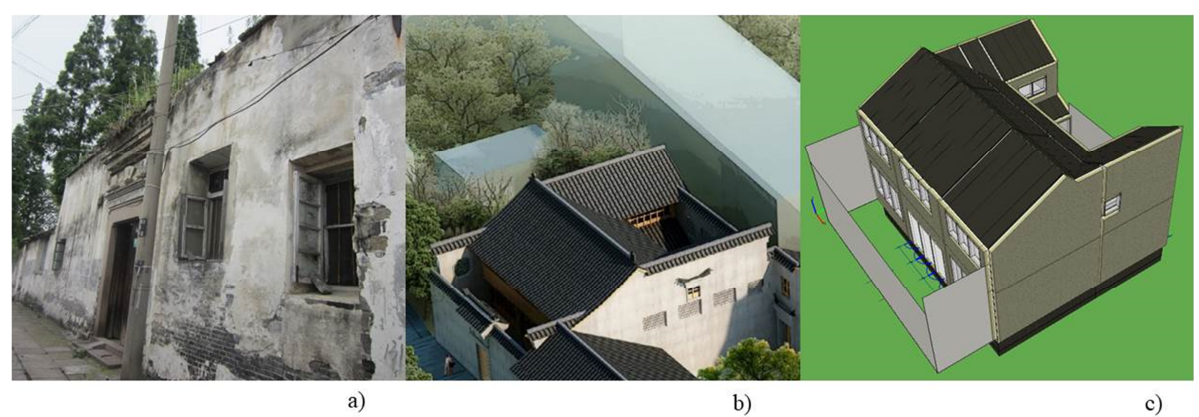

Fig. 2. a) Real photo of Author 1, a) A1 rendering picture c) IDA ICE simplified 3D simulation model

\subsection{The local climate}

Shanghai is located in the plain water area of the Jiangnan region of China. It belongs to the subtropical monsoon climate, with hot and humid summers and cold and wet winters. The climate of Shanghai is moderate and humid all year round with maximum temperatures exceeding $36{ }^{\circ} \mathrm{C}$ [9]. In summer, from June to August, the average temperature is measured at $26.7^{\circ} \mathrm{C}$. The average temperature of hottest month (July) is 28 Celsius and the highest temperature recorded was 38 Celsius (Fig. 3). The average relative humidity is $80 \%$ and the prevailing wind is Southeast wind with an average wind speed of 2.6-4.0 m/s. In winter, from December to February, the average temperature is $5.7{ }^{\circ} \mathrm{C}$. The average temperature of coldest month (January) is $4{ }^{\circ} \mathrm{C}$ and the lowest temperature recorded was $-6{ }^{\circ} \mathrm{C}$. The average relative humidity is $30 \%$ and the prevailing wind is Northwest wind with an average wind speed of $2.6-3 \mathrm{~m} / \mathrm{s}$. In autumn from September to November the average temperature is $18.1{ }^{\circ} \mathrm{C}$ while during spring from March to May the average temperature is $14.5^{\circ} \mathrm{C}$. The above analysis is based on Shanghai meteorological data from ASHRAE in IDA ICE [9].

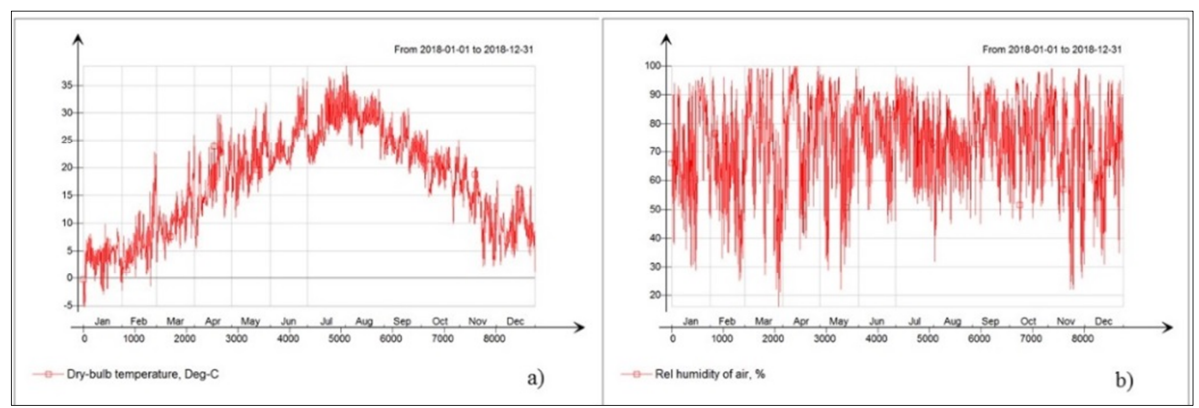

Fig. 3. Shanghai, China weather data, a) Dry-bulb temperature; b) relative humidity 


\subsection{Materials and their thermal properties}

In Wang's House, the ceilings are made of wood and the perimeter walls are made of Chinese blue brick [10]. The brick is a traditional process in which clay is blended with water and calcined in a brick kiln. The brick is then water cooled in order to completely oxidize the iron in the clay to form a low-cost iron (FeO). The interior walls are wood; all exterior doors are wood; all existing windows are made by wood and glass, 1-pane glazing. In the second floor, the floor slab is Chinese fir wood and the roof is made up of blue clay tiles [10] with Chinese fir as the supporting rafters. There is no heating ventilation and air-conditioning (HVAC) building system in this house. The materials specifications as input the data for IDA ICE are depicted in Table I and Table II.

Table I

The existing building materials used in Wang's House

\begin{tabular}{|c|c|c|c|c|c|}
\hline Location & Material & $\begin{array}{l}\text { Size }(\mathrm{mm}) \\
\text { LxWxH } \\
\text { Thickness of } \\
\text { material }\end{array}$ & $\begin{array}{l}\text { Thermal } \\
\text { conductivity } \\
\lambda \mathrm{W} /(\mathrm{m} \cdot \mathrm{K})\end{array}$ & $\begin{array}{l}\text { Specific } \\
\text { heat c } \\
\mathrm{J} /(\mathrm{kg} \cdot \mathrm{K})\end{array}$ & $\begin{array}{l}\text { Density } \\
\rho \\
\left(\mathrm{kg} / \mathrm{m}^{3}\right)\end{array}$ \\
\hline Wall & Blue brick [10] & $\begin{array}{l}240 \times 120 \times 60 \\
\text { totally } 240 \\
\text { thickness }\end{array}$ & 0.65 & 860 & 2000 \\
\hline $\begin{array}{l}\text { First } \\
\text { floor }\end{array}$ & Bluestone [10] & $300 \times 300 \times 20$ & 0.18 & 920 & 1100 \\
\hline $\begin{array}{l}\text { Second } \\
\text { floor } \\
\text { slab }\end{array}$ & Chinese fir wood & 150 widths & 0.14 & 2300 & 500 \\
\hline Roof & $\begin{array}{l}\text { Rafter (Chinese fir) } \\
\text { Wang Brick } \\
\text { Huibei (Lime cream } \\
\text { and fine clay) }\end{array}$ & $\begin{array}{l}700 \times 70 \times 40 \\
210 \times 105 \times 17 \\
50 \text { thickness }\end{array}$ & $\begin{array}{l}0.14 \\
0.65 \\
1.41\end{array}$ & $\begin{array}{l}2300 \\
860 \\
1900\end{array}$ & $\begin{array}{l}500 \\
2000 \\
1000\end{array}$ \\
\hline & $\begin{array}{l}\text { Waterproof } \\
\text { membrane (sbc120) }\end{array}$ & 1 thickness & 0.5 & 1700 & 1000 \\
\hline window & $\begin{array}{l}\text { Tile } \\
\text { Wood and Glass }\end{array}$ & $200 \times 160 \times 10$ & 0.498 & 1121 & 837 \\
\hline door & Wood & 40 widths & 0.14 & 2300 & 500 \\
\hline
\end{tabular}

Table II

Glass parameters

\begin{tabular}{|c|c|c|c|c|c|c|}
\hline & 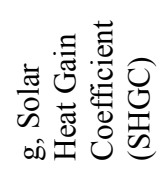 & 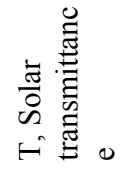 & 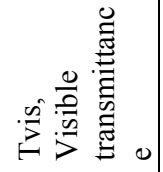 & 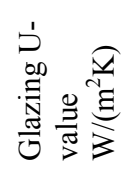 & 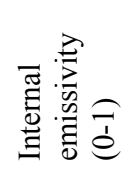 & 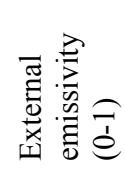 \\
\hline Glass & 0.85 & 0.83 & 0.9 & 5.8 & 0.837 & 0.837 \\
\hline
\end{tabular}

Pollack Periodica 14, 2019, 1 


\section{Methodology}

In this study, the thermal 3D model was generated in IDA ICE 4.8 dynamic energy and climate simulation program [11]. The boundary conditions have been set precisely due to actual condition of the building, before generating the thermal model [12], [13]. The materials specifications for instance the thermal conductivity $(\mathrm{W} /(\mathrm{m} \cdot \mathrm{K})$, density $\left(\mathrm{kg} / \mathrm{m}^{3}\right)$ and specific heat $\mathrm{J} /(\mathrm{kg} \cdot \mathrm{K})$ were then assigned for the basement, external walls, internal walls and the roof. The orientation of the house and the climactic conditions of Shanghai was then used in IDA ICE weather data file (ASHRAE IWE). The thermal bridges for the external wall, window, floor slab and roof were set between poor and very poor considering the actual situation of the house (External Wall/Internal Slab: $0.5 \mathrm{~W} / \mathrm{K} /$ (m joint, External Wall/Internal Wall: $0.5 \mathrm{~W} / \mathrm{K} /$ (m joint), External Wall/External wall:0.272 W/K/ (m joint), External windows perimeter: $0.616 \mathrm{~W} / \mathrm{K} /(\mathrm{m}$ perim), External Doors perimeter: $0.616 \mathrm{~W} / \mathrm{K} /$ (m perim), Roof/External Walls: $0.544 \mathrm{~W} / \mathrm{K} /$ (m joint), External Slab/External walls: $0.78 \mathrm{~W} / \mathrm{K} /$ (m joint), Balcony Floor/External walls: $0.928 \mathrm{~W} / \mathrm{K} /$ (m joint), External Slab/Internal walls: $0.272 \mathrm{~W} / \mathrm{K} /(\mathrm{m}$ joint), Roof/Internal walls: $0.256 \mathrm{~W} / \mathrm{K} /$ ( $\mathrm{m}$ joint), External walls, Inner corner: $0.034 \mathrm{~W} / \mathrm{K} /$ (m joint), External Slab/External Walls/Inner corner: $-0.0216 \mathrm{~W} / \mathrm{K} /(\mathrm{m}$ joint), Roof/External Walls, Inner corner: $-0.0272 \mathrm{~W} / \mathrm{K} /$ (m joint)). Pressure coefficients set to 'semi exposed' due to the location of the house. Additionally, ten zones were specified in this study and each of these zones differs in the number of occupants, equipment and lighting. In this analysis, one occupant was assumed in each zone while two occupants were assumed in the living room. The heating-cooling temperature setpoints were defined between $21-25{ }^{\circ} \mathrm{C}$, relative humidity between $20-80 \%$ and $\mathrm{CO}_{2}$ at 700-1100 ppm. The objective of the paper is to have an assessment of energy demand of the building with respect to the required thermal comfort. Since in first step of the investigations focuses on architectural properties, the authors used simplified ideal heater and cooler in the models, without specific definition of different HVAC systems. The schedule has been created base on the former experience in such a family houses. In this schedule, the whole year has been divided into to 3 main season which are heating \& cooling season and transaction season. For example, from January 1st until 28th of February in workdays the windows are open twice, for each time 5 minutes, once is between 8:00-8:05 and afternoon 17:00-17:05 and at weekend and holidays it is open 3 times and each time 5 minutes, 9:00-9:05, 12:00-12:05 and 15:00-15:05. Windows and frames are set to 1 pane glazing with solar heat gain coefficient of 0.85 , the solar transmittance of 0.83 and light transmittance of 0.9 , respectively. The frame u-value was set at $2.0 \mathrm{~W} /\left(\mathrm{m}^{2 \circ} \mathrm{C}\right)$, glazing value at $5.8 \mathrm{~W} /\left(\mathrm{m}^{2} \mathrm{~K}\right)$, internal emissivity at 0.837 and external emissivity at 0.837 , respectively. Finally, in this analysis, only the storage, kitchen storage and stair case are considered as the lower comfort conditions variables, because these are inhabitable spaces and therefore the usage of these areas are low. Thus, the temperature settings for these zones were set between $18-27^{\circ} \mathrm{C}$. 


\section{Results and discussions}

From the resulting analysis in Table III it can be perceived that $76 \%$ of the total annual energy demand was used on heating the building while $15 \%$ was used on cooling and $7.9 \%$ on lighting, respectively.

The general information and thermal behavior of the given zones with respect to the total energy demand (44885.2 $\mathrm{kWh}$ ) are shown in Table $\mathrm{IV}$.

The energy balance information of Wang's House is shown in Table $V$. The various heating and cooling energy loss are dependent on: the building envelope, walls, openings, number of occupants, equipment, lighting, local heating and cooling. The thermal loss of the envelope and thermal bridges is as high as $26178.9 \mathrm{kWh}$, the heat loss from window solar reaches $5660.6 \mathrm{kWh}$, and the total energy consumption for heating is $34132.8 \mathrm{kWh}$. Furthermore, the highest heat loss is due to the building envelope and the thermal bridges especially during the winter season.

Table III

Annual delivered energy

\begin{tabular}{|l|c|c|c|}
\hline Meter & Total $(\mathrm{kWh})$ & Per $\mathrm{m} 2\left(\mathrm{kWh} / \mathrm{m}^{2}\right)$ & Peak demand $(\mathrm{kW})$ \\
\hline Lighting, facility & 3567.5 & 19.89 & 1.221 \\
Electric cooling & 6782.5 & 37.81 & 13.39 \\
Electric heating & 34133.9 & 190.3 & 31.48 \\
Equipment, tenant & 401.3 & 2.237 & 0.1978 \\
\hline Total & 44885.2 & 250.2 & 46.29 \\
\hline
\end{tabular}

Table IV

General information of the zones (annual average)

\begin{tabular}{|l|l|l|l|l|l|l|}
\hline & $\begin{array}{l}\text { Min } \\
\text { Temp } \\
\left({ }^{\circ} \mathrm{C}\right)\end{array}$ & $\begin{array}{l}\text { Max } \\
\text { Temp } \\
\left({ }^{\circ} \mathrm{C}\right)\end{array}$ & $\begin{array}{l}\text { Max Heat } \\
\text { Supplied } \\
\left(\mathrm{W} / \mathrm{m}^{2}\right)\end{array}$ & $\begin{array}{l}\text { Max Solar } \\
\text { gain } \\
\left(\mathrm{W} / \mathrm{m}^{2}\right)\end{array}$ & $\begin{array}{l}\text { Min Rel } \\
\text { hum. } \\
(\%)\end{array}$ & $\begin{array}{l}\text { Max } \\
\text { Rel } \\
\text { hum. } \\
(\%)\end{array}$ \\
\hline Bedroom 1 & 20.88 & 25.1 & 105.3 & 97.32 & 11.25 & 100 \\
Bedroom 2 & 20.88 & 25.1 & 102.6 & 97.78 & 11.93 & 100 \\
Bedroom 3 & 20.85 & 25.13 & 125 & 107.5 & 11.81 & 100 \\
Bedroom 4 & 19.76 & 25.23 & 145.5 & 109.1 & 11.71 & 100 \\
Bedroom 5 & 20.89 & 25.09 & 96.32 & 91.52 & 11.75 & 100 \\
Kitchen Storage & 15.61 & 26.74 & 426.5 & 282.2 & 12.41 & 90.31 \\
Stair & 15.74 & 27.9 & 173.4 & 44.73 & 13.71 & 97.9 \\
Storage & 17.88 & 27.16 & 180 & 104.6 & 13.66 & 93.13 \\
Living Room & 17.82 & 25.1 & 113.2 & 48.99 & 11.27 & 94.9 \\
Kitchen & 16.87 & 25.14 & 109.8 & 219.7 & 11.53 & 90.29 \\
\hline
\end{tabular}

In Fig. 4 and Fig. 5 the Parts Per Million (PPM) graphs demonstrate that the $\mathrm{CO}_{2}$ level of the chosen thermal zones, means two bedrooms, living room and kitchen. The data shows that the $\mathrm{CO}_{2}$ concentration rate in the month of June, July, August and September were relatively low due to the more frequent opening of the windows and higher air exchange rate which resulted in better air quality. 
Table V

Energy balance of the Wang's House

\begin{tabular}{|c|c|c|c|c|}
\hline & Total & During heating & During cooling & $\begin{array}{c}\text { Rest of } \\
\text { time }\end{array}$ \\
\hline $\begin{array}{c}\text { Envelope \& Thermal } \\
\text { Bridges }(\mathrm{kWh})\end{array}$ & -23752.1 & -26178.9 & 4497.8 & -2071 \\
$\begin{array}{c}\text { Internal Walls and Masses } \\
\text { (kWh) }\end{array}$ & -26.5 & 647.6 & -793.3 & 119.2 \\
Window \& Solar (kWh) & -469.4 & -5660.6 & 4675.6 & 515.6 \\
Infiltration \& Openings & & & & \\
(kWh) & -2746.2 & -5981.4 & 2523.4 & 711.8 \\
Occupants (kWh) & 2398.7 & 1143.8 & 962.9 & 292 \\
Equipment $(\mathrm{kWh})$ & 401.3 & 210 & 143.3 & 48 \\
Lighting $(\mathrm{kWh})$ & 3567.5 & 1670.7 & 1515.7 & 381.2 \\
Local heating units $(\mathrm{kWh})$ & 34133.8 & 34132.8 & 0 & 1 \\
Local cooling units $(\mathrm{kWh})$ & -13456.4 & 0 & -13456.5 & 0.1 \\
\hline
\end{tabular}

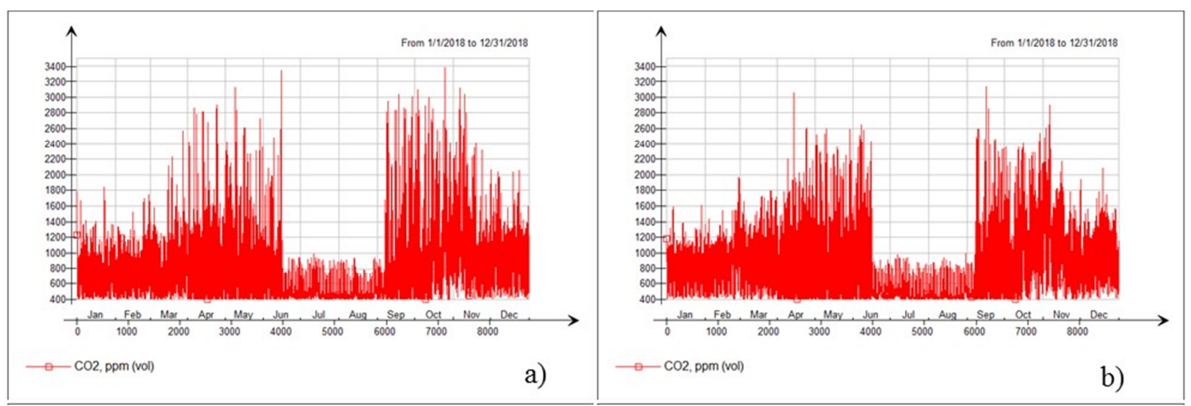

Fig. 4. $\mathrm{CO}_{2}$, ppm volume, a) Bedroom \#2, b) Bedroom \#4

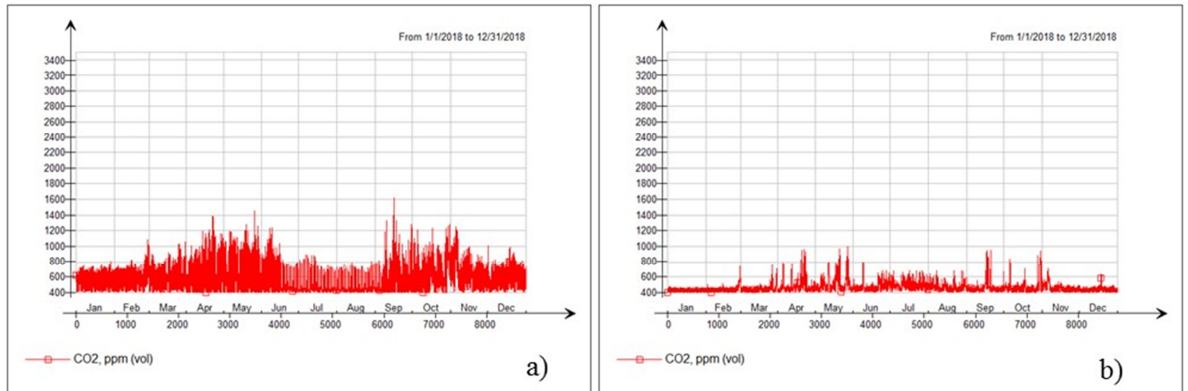

Fig. 5. $\mathrm{CO}_{2}$, ppm volume, a) Living room, b) Kitchen

Fig. 6 and Fig. 7 show that the living room has the best Predicted Mean Vote (PMV) rate compared to other thermal zones. This is due to the presence of more openings during the summer periods. Furthermore, the presence of the one external wall had an effect on the resulting PMV rate. The living room is in middle of the apartment and it is 
surrounded by the heated zones, it will prevent the zone against the thermal bridges since the living room is not connected to outside temperature directly. In Table VI, Fig. 8 and Fig. 9 the annual thermal comfort percentage rates of the zones are shown. From this analysis, the best thermal comfort is in the months of January to March and November to December.

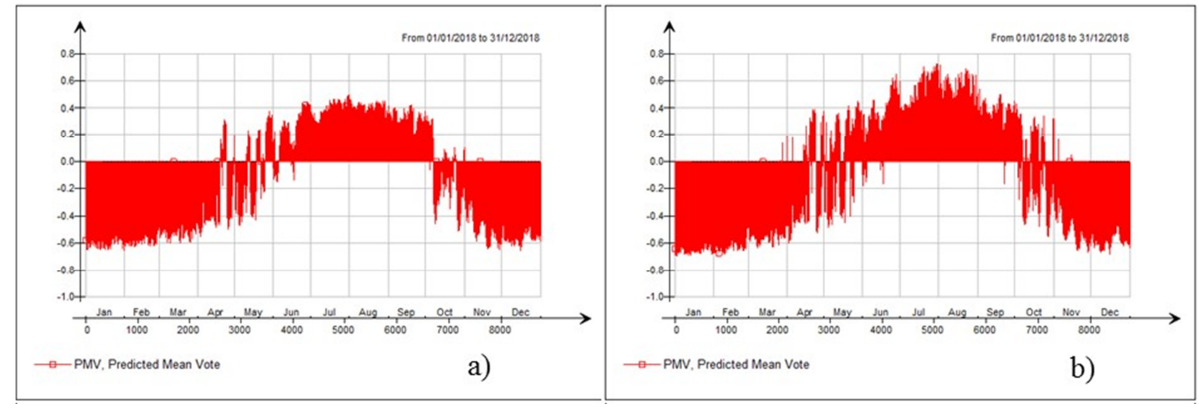

Fig. 6. PMV (Predicted mean vote), a) Bedroom \#2, b) Bedroom \#4

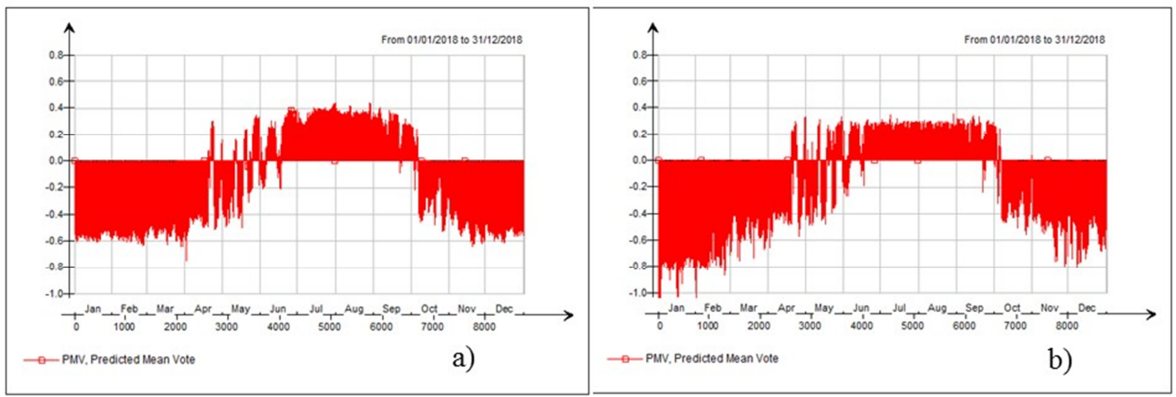

Fig. 7. PMV (Predicted mean vote), a) Living room, b) Kitchen

Table VI

Thermal comfort percentage rates selected zones

\begin{tabular}{|l|c|c|c|c|}
\hline Zones & Best [\%] & Good [\%] & Acceptable [\%] & Unacceptable [\%] \\
\hline Bedroom 2 & 63.3 & 20.0 & 15.5 & 1.2 \\
Bedroom 4 & 48.3 & 37.6 & 12.0 & 2.0 \\
Living room & 57.2 & 23.7 & 17.5 & 1.6 \\
Kitchen & 43.3 & 32.0 & 22.1 & 2.6 \\
\hline
\end{tabular}

Fig. 10 and Fig. 11 show that most time of the year relative humility is above $70 \%$ due to the local high relative humility of Shanghai climate, it is quite uncomfortable during summer time with high temperature.

Fig. 12 and Fig. 13 show that second floor rooms' daylight is better than first floor rooms because of the barrier of the courtyard wall. The living room's daylight performed worst due to the depth is deeper. 

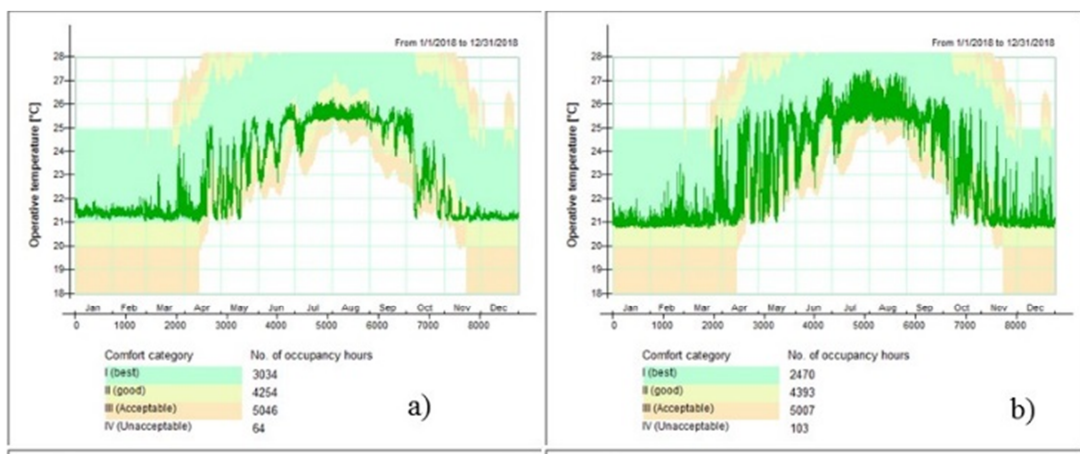

Fig. 8. Operative temperature and comfort category, a) bedroom \#2, b) bedroom \#4
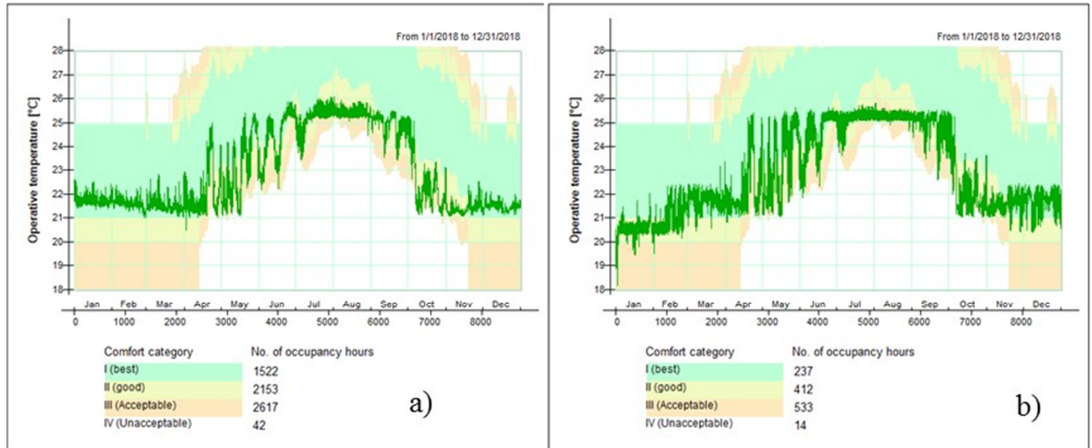

Fig. 9. Operative temperature and comfort category, a) Living room, b) Kitchen.

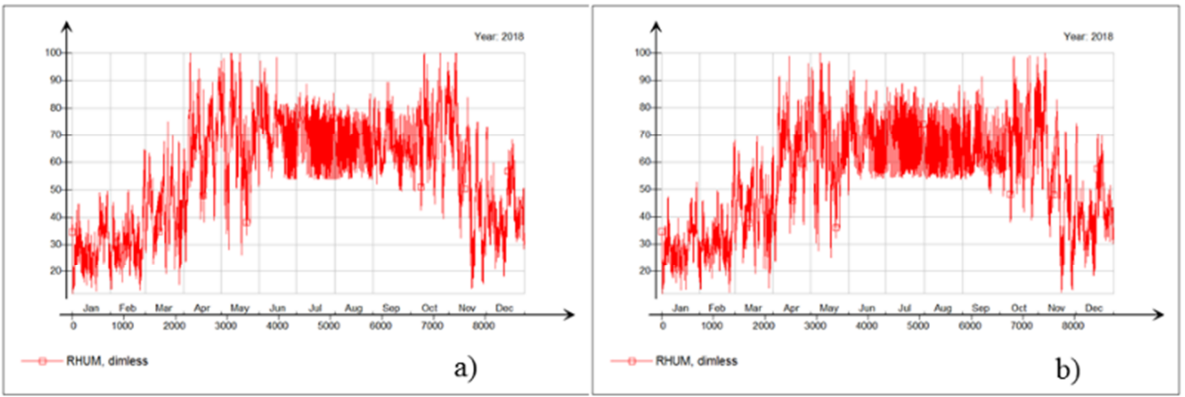

Fig. 10. RHUM (Relative humidity), a) Bedroom \#2, b) Bedroom \#4

For future studies, the proper size of thermal insulation, the new frame and glass type of windows and doors which belonging to material modifications, different radiative, convective or conductive heat transfer system, different plants and energy sources like geothermal earth probes, liquid chiller, gas etc. are determined by next research. (Table VII). 


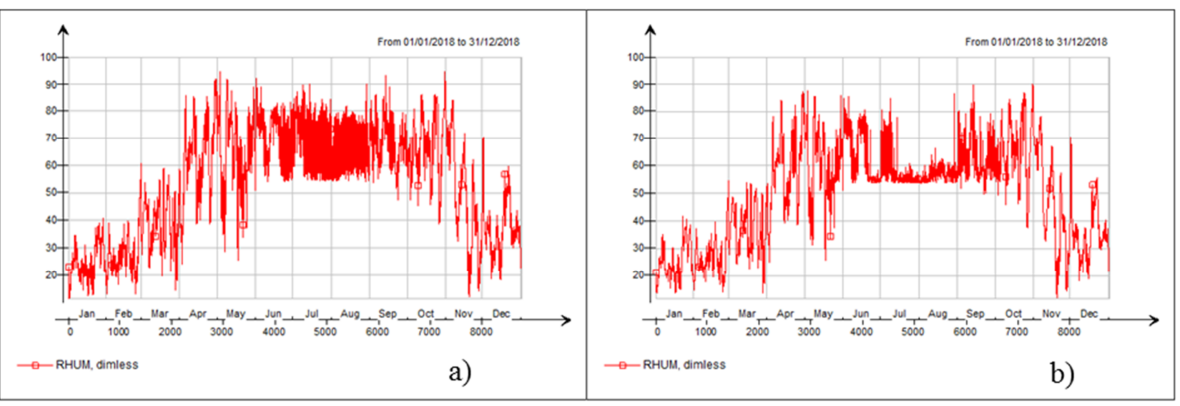

Fig. 11. RHUM (Relative humidity), a) Living room, b) Kitchen

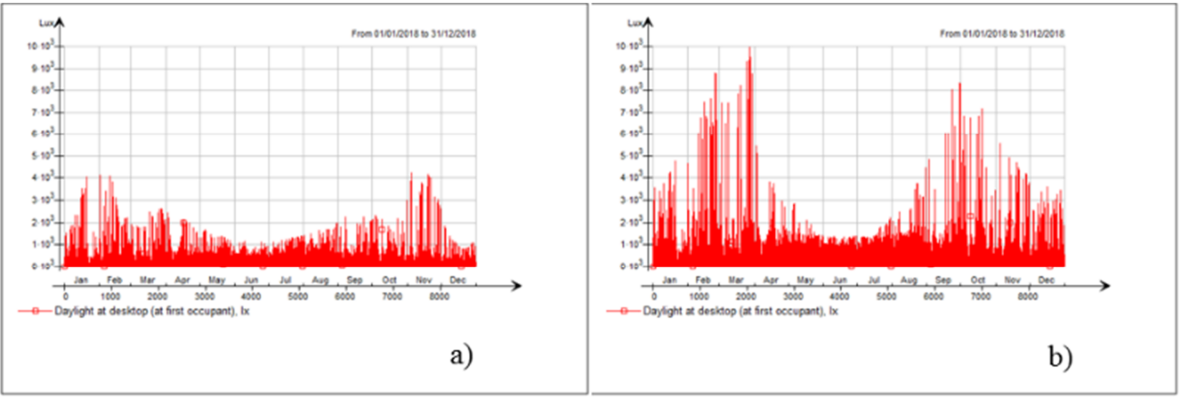

Fig. 12. Daylight, a) Bedroom \#2, b) Bedroom \#4

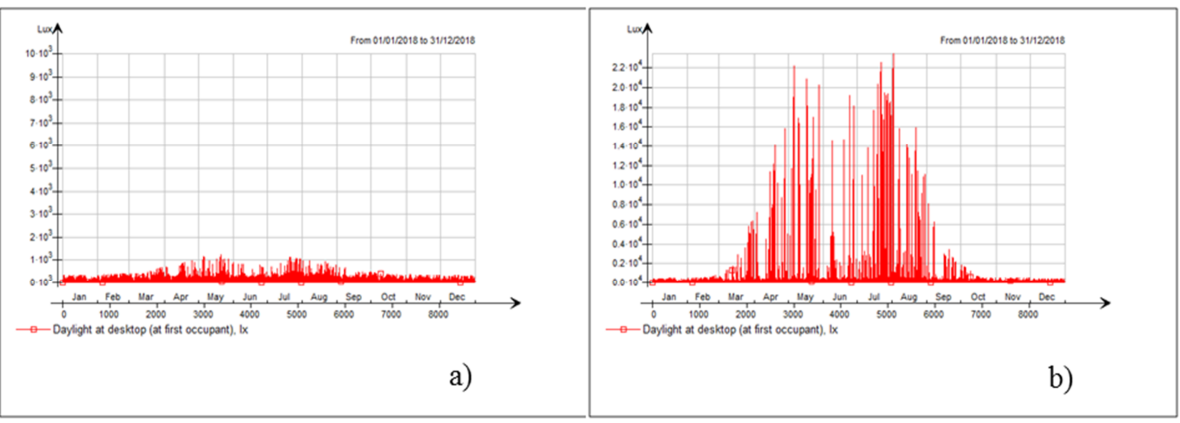

Fig. 13. Daylight, a) Living room, b) Kitchen

\section{Conclusion and future studies}

The main goal of the Wang House project is to decide the most optimal solution based on the concept of the refurbishment, which is to preserve the historical building without destroying the cultural heritage of the building and having the best solution energy, comfort and aesthetics. The current situation of the building should be investigated to expose the failures, weakness and future potential improvements. Due to

Pollack Periodica 14, 2019, 1 
this reasons a yearly energy simulation assessment was performed on Wang's House using the dynamic thermal simulation software, IDA ICE. Based on the investigation, the amount of energy required for lighting, cooling and heating was also being identified. From the resulting information, $76 \%$ of the annual total energy being used was on heating the entire house. This is evident because of the absence of thermal insulation (walls and glazing) on the house. Furthermore, due to the poor thermal bridges and the building envelope, the cooling energy consumption is only about $1 / 3$ of the heating energy consumption. At the same time it is lack of enough thermal mass. Thermal insulation as well as thermal mass (structures or PCM) should be added in order to increase thermal comfort and energy performance. Additionally, from the resulting investigation $15 \%$ of the annual total energy used was on cooling and $7.9 \%$ on lighting. The use of passive and active sustainable strategies can decrease energy use, especially during summer and winter time, also using proper type of HVAC system will influence the thermal comfort in a very effective way. By respect to this information the next step for the pre refurbishment phase has been illustrated and the critical points which need improvements are known. By applying these sustainable strategies as well as modifying the materials used in the house, detailed investigation will be carry on to decide the best refurbishment strategy.

Table VII

The optimization strategies based on existing situation for next step

\begin{tabular}{|c|c|c|c|c|c|c|c|c|c|c|}
\hline \multirow{2}{*}{\multicolumn{2}{|c|}{ Problems and critical points }} & \multicolumn{3}{|c|}{ Comfort } & \multicolumn{6}{|c|}{ Energy } \\
\hline & & 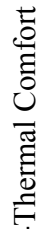 & 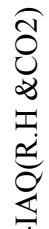 & 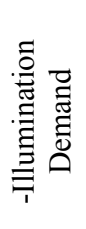 & 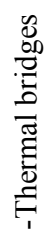 & 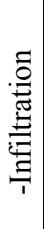 & 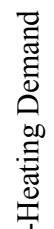 & 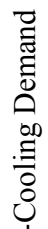 & 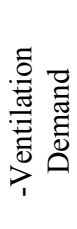 & 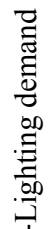 \\
\hline $\begin{array}{l}\text { Passive } \\
\text { Strategies }\end{array}$ & $\begin{array}{l}\text { Rearrangement of } \\
\text { spaces (orientation) } \\
\text { Thermal insulation } \\
\text { Glazing, window, } \\
\text { Lighting } \\
\text { Thermal Mass } \\
\text { Shading } \\
\text { Operation strategies for } \\
\text { passive ventilation }\end{array}$ & $\begin{array}{l}+ \\
+ \\
+ \\
+ \\
+ \\
+\end{array}$ & + & + & + & + & $\begin{array}{l}+ \\
+ \\
+ \\
+ \\
+ \\
+\end{array}$ & $\begin{array}{l}+ \\
+ \\
+ \\
+\end{array}$ & + & + \\
\hline $\begin{array}{l}\text { Active } \\
\text { Strategies }\end{array}$ & $\begin{array}{l}\text { Different heating - } \\
\text { cooling transfer system } \\
\text { HVAC system size } \\
\text { Ventilation system } \\
\text { Automation } \\
\text { Operation strategies for } \\
\text { heating, cooling and } \\
\text { mechanical ventilation } \\
\text { Photovoltaic }\end{array}$ & $\begin{array}{l}+ \\
+ \\
+ \\
+ \\
+\end{array}$ & $\begin{array}{l}+ \\
+ \\
+ \\
+\end{array}$ & + & & & $\begin{array}{l}+ \\
+ \\
+ \\
+\end{array}$ & $\begin{array}{l}+ \\
+ \\
+ \\
+\end{array}$ & $\begin{array}{l}+ \\
+ \\
+ \\
+ \\
+\end{array}$ & + \\
\hline
\end{tabular}




\section{Acknowledgements}

This work has been undertaken by the students and professors as a part of a project founded by the Faculty of Engineering and Information Technology, University of Pécs, We would also like to appreciate the assistance of Dr. Istvan Kistelegi of the Energy Design Research Group, Faculty of Engineering and Information Technology, University of Pécs.

\section{Open Access statement}

This is an open-access article distributed under the terms of the Creative Commons Attribution 4.0 International License (https://creativecommons.org/licenses/by/4.0/), which permits unrestricted use, distribution, and reproduction in any medium, provided the original author and source are credited, a link to the CC License is provided, and changes - if any - are indicated. (SID_1)

\section{References}

[1] International Energy Agency, World Energy Outlook 2012, Paris Google Scholar, 2012.

[2] Jiang, Y., Wu X. Annual report on China building energy efficiency, (in Chinese) China Architecture \&Building Press, Beijing (2010) (2010).

[3] Harrestrup M., Svendsen S. Full-scale test of an old heritage multi-storey building undergoing energy retrofitting with focus on internal insulation and moisture, Building and Environment, Vol. 85, 2015, pp. 123-133.

[4] Pisello A. L., Petrozzi A., Castaldo V. L., Cotana F. On an innovative integrated technique for energy refurbishment of historical buildings: Thermal-energy, economic and environmental analysis of a case study, Applied Energy, Vol. 162, 2016, pp. 1313-1322.

[5] Wang F., Ma X. B., Li Z. Y. Climate responsive strategy of a vernacular village in middle region of Zhejiang province, (in Chinese) Acta Energiae Solaris Sinica, Vol. 35, No. 8, 2014, pp. 1486-1492.

[6] Liu D. L., Yang J. P., Hu R. R. Ecological folk house and indoor thermal environment in Northwest China, (in Chinese) Industrial Construction, Vol. 2, 2012, pp. 19-22.

[7] Iyer-Raniga U., Wong J. P. C. Evaluation of whole life cycle assessment for heritage buildings in Australia, Building and Environment, Vol. 47, 2012, pp. 138-149.

[8] Chu X. H., Lyu A. M. Study on the passive cooling design strategies of traditional architecture in Jiangnan Region and application, (in Chinese) Environmental Architecture, Vol. 8, No. 5, 2014, pp. 57-60.

[9] Liedl P., Hausladen G., Saldanha M. Building to Suit the Climate: A Handbook, Walter de Gruyter, 2012.

[10] Song Y. X., Sun E. Z., Sun S. Chinese technology in the seventeenth century, Courier Corporation, 1997.

[11] Kővári G. Kistelegdi I. Building performance simulation modeling techniques, Pollack Periodica, Vol.11, No. 2, 2016, pp. 135-146.

[12] Póth B., Kistelegdi I. Energy and climate simulations and management system in the Szentágothai research center, Pollack Periodica, Vol. 9, No. 1, 2014, pp. 61-70.

[13] Radha C. H., Kistelegdi I. Thermal performance analysis of Sabunkaran residential building typology, Pollack Periodica, Vol. 12, No. 2, 2017, pp. 151-162. 